\title{
RASTISLAV ŠUŠTARŠIČ: BIBLIOGRAPHY
}

\section{MONOGRAPHS}

(1989) Prevzemanje angleških slovarskih enot v slovenščino: fonološko prilagajanje. MA Thesis, University of Ljubljana.

(1993) Kontrastivna analiza angleške in slovenske stavčne intonacije. Doctoral dissertation, University of Ljubljana.

(1996) Present-Day English Pronunciation: A Guide for Slovene Students. Ljubljana: Filozofska fakulteta, Oddelek za germanske jezike in književnosti. [Co-authored with Beverley Collins/Smiljana Komar].

(2002) Present-Day English Pronunciation: A Guide for Slovene Students. Revised and enlarged 2nd ed. Ljubljana: Filozofska fakulteta, Oddelek za anglistiko in amerikanistiko. [Co-authored with Beverley Collins/Smiljana Komar]. Reprinted in 2008, 2012 and 2014. (2005) English-Slovene Contrastive Phonetic and Phonemic Analysis and its Application in Teaching English Phonetics and Phonology. Ljubljana: Znanstveni inštitut Filozofske fakultete.

\section{STUDIES AND ARTICLES}

(1990) "Fonološko prilagajanje soglasnikov v angleških slovarskih enotah, prevzetih v slovenščino." Slavistična revija 38/2, 141-156.

(1991) "Izgovarjava angleških besed: predlogi k pravilom novega slovenskega pravopisa." Jezik in slovstvo 36/3, 62-69.

(1993) "Izgovorjava in fonemska transkripcija angleškega pogovornega jezika - analiza napak študentov angleškega jezika." Vestnik DTJK 27/1-2, 31-54.

(1994) "Kontrastivna analiza angleške in slovenske stavčne intonacije." Vestnik DTJK 28/1-2, 31-47.

(1995) "Naglas in poudarek v angleščini in slovenščini." Slavistična revija 43/2, 157-182. (1995) "Pitch and Tone in English and Slovene." Linguistica 35/2, 91-106.

(1995) "Slovene: Illustrations of the IPA." Journal of the International Phonetic Association 25/2, 86-90. [Co-authored with Smiljana Komar/Bojan Petek].

(1996) "An Acoustic Analysis of Contemporary Vowels of the Standard Slovenian Language." In: H. T. Bunnell/W. Idsardi (eds), Proceedings ICSLP 96, Fourth International Conference on Spoken Language Processing, October 3-6, 1996, Philadelphia, PA, USA. Vol. 1. Wilmington (DE): University of Delaware/Apllied Science and Engineering Laboratories/Alfred I. du Point Institute, 133-136. [Co-authored with Bojan Petek/Smiljana Komar].

* kristina.pegan@ff.uni-lj.si 
(1996) "Computer-Aided Formation of Spelling-to-Pronunciation Rules in English." Vestnik DTJK 30/1-2, 183-198.

(1996) "Kaj lahko sami naredimo za boljšo angleško izgovorjavo." In: S. Benulič (ed.), Angleščina pri maturi: kako se uspešno pripravimo na preizkus znanja iz angleškega jezika. Ljubljana: Republiški izpitni center, 92-97.

(1997) "Contrastive Error Analysis of English Phonemic Transcriptions Based on Written and Oral Text Presentation." In: J. Leather/A. James (eds), New Sounds 9: Proceedings of the Third International Symposium on the Acquisition of SecondLanguage Speech (University of Klagenfurt, 8-11 September 1997). Klagenfurt: University of Klagenfurt, 331-335.

(1997) “A Corpus-Based Approach to Diphthong Analysis of Standard Slovenian.” In: G. Kokkinakis (ed.), Eurospeech '97: Proceedings: 5th European Conference on Speech Communication and Technology, Rhodes - Greece, 22-25 September 1997. Vol. 2. Patras: University of Patras, 767-782. [Co-authored with Bojan Petek].

(1998) "Slovensko-angleška protistavna analiza angleškega nedoločnika $v$ funkciji osebka." Vestnik DTJK 32/1-2, 299-320. [Co-authored with Nike Kocijančič Pokorn]. (1998) “Using Phonemic Transcription at the University Level." In: R. de Beaugrande/M. Grosman/B. Seidlhofer (eds), Language Policy and Language Education in Emerging Nations: Focus on Slovenia and Croatia and with Contributions from Britain, Austria, Spain, and Italy. Stamford/London: Ablex Publishing Corp., 183-189.

(1999) "Assimilation and Elision in English and Slovene." Govor 16/1, 15-23.

(1999) "A Contrastive Approach to Teaching English Pronunciation for Slovene Students of English." In: ICPhS 99: Proceedings of the 14th International Congress of Phonetic Sciences, San Francisco, 1-7 August 1999. Vol. 1. Berkeley: University of California, 763-765.

(1999) "The Role of the Mother Tongue in Teaching English Pronunciation." In: J. A. Maidment/E. Estebas-Vilaplana (eds), PTLC 1999: Proceedings of the Phonetics Teaching \& Learning Conference, University College London, April 14-15, 1999. London: University College/Department of Phonetics \& Linguistics, 73-77.

(1999) "Slovene." In: Handbook of the International Phonetic Association: A Guide to the Use of the International Phonetic Alphabet. Cambridge: Cambridge University Press, 135-139. [Co-authored with Smiljana Komar/Bojan Petek].

(1999) "Slovensko-angleška protistavna analiza nedoločnika v vlogi premega predme-

ta." Vestnik DTJK 33/1-2, 267-281. [Co-authored with Nike Kocijančič Pokorn].

(2001) "Otvorena pitanja standardnoga slovenskog izgovora." Govor 18/2, 113-122. [Co-authored with Hotimir Tivadar].

(2001) "Slovensko-angleška protistavna analiza nedoločnika v vlogi osebkovega oz. povedkovega določila." Slovenski jezik=Slovene Linguistic Studies 3, 32-41. [Coauthored with Nike Kocijančič Pokorn].

(2001) "Using a Speech Recognition Program in Teaching English Pronunciation." In: J. A. Maidment/E. Estebas-Vilaplana (eds), PTLC 2001: Proceedings of the Phonetics Teaching \& Learning Conference, April 5-7, 2001. London: Department of Phonetics \& Linguistics/UCL, 47-50. 
(2002) "General and Specific Features of Sound Systems." In: Measurement of Speech Sound Data and its Practical Application: Conference and Proceedings: The 1st International Conference on Speech Sciences (ICSS), May 10-11, 2002, Korea University, Seoul. Seoul (Korea): KASS/KT, 105-113.

(2002) "Poetics and Phonetics: Using Poetry in Teaching English Pronunciation." In: A. James/J. Leather (eds), New Sounds 2000: Proceedings of the Fourth International Symposium on the Acquisition of Second-Language Speech (University of Amsterdam, September 200). Klagenfurt: University of Klagenfurt, 335-342.

(2002) "Računalniško podprto učenje angleščine: kratek pregled njegovega dosedanjega razvoja." In: D. Stolac/N. Ivanetić/B. Pritchard (eds), Primijenjena lingvistika u Hrvatskoj: izazovi na početku XXI. stoljeća: zbornik. Zagreb/Rijeka: Hrvatsko društvo za primijenjenu lingvistiku/Graftrade, 541-545.

(2003) “Application of Acoustic Analysis in English Phonetics Teaching.” In: M. J. Solé/ D. Recasens/J. Romero (eds), Proceedings of the 15th International Congress of Phonetic Sciences [also] 15th ICPhS, Barcelona 3-9 August 2003. Barcelona: Universitat Autònoma de Barcelona, 2841-2844. https://www.internationalphoneticassociation.org/icphs-proceedings/ICPhS2003/papers/p15_2841.pdf

(2004) “A Contrastive Analysis of the Vowel Qualities of English and Slovene.” In: E. González-Álvarez/A. Rollings (eds), Studies in Contrastive Linguistics. Santiago de Compostela: Universidade de Santiago de Compostela, 601-608.

(2005) "Dictionary Transcriptions Representing Standard British and American Pronunciations and Their Application in Teaching English Phonetics.” In: J. A. Maidment (ed.), PTLC 2005: Proceedings. London: University College London/Department of Phonetics and Linguistics, 1-4. https://www.ucl.ac.uk/pals/study/cpd/ cpd-courses/ptlc/proceedings_2005

(2005) "Perception of Tonemicity in Standard Slovene." Govor 22/1, 23-35. [Co-authored with Hotimir Tivadar].

(2005) "Phonemic Transcriptions in British and American Dictionaries." ELOPE 2/12, 87-95. http://dx.doi.org/10.4312/elope.2.1-2.87-95

(2007) "English-Slovene Contrastive Analysis: Phonological Adaptation of English Vowels in Slovene." In: D. Točanac/M. Jovanović (eds), Primenjena lingvistika danas: izabrani radovi sa II kongresa LDPL Srbije, Filološki fakultet, Beograd, 28-30 septembar. Beograd/Novi Sad: Jugoslovensko društvo za primenjenu lingvistiku, 53-65. (2007) "Using Speech Archives in Teaching English Pronunciation.” In: J. A. Maidment (ed.), Proceedings: Phonetics Teaching and Learning Conference 2007, London, 24-26 August 2007. London: University College London/Department of Phonetics and Lingustics, 1-4. https://www.ucl.ac.uk/pals/study/cpd/cpd-courses/ptlc/ proceedings_2007

(2008) "Application of a Speech Archive Analysis to English Pronunciation Teaching." In: A. Schurt Rauber/M. A. Watkins/B. O. Baptista (eds), New Sounds 2007: Proceedings of the Fifth International Symposium on the Acquisition of Second Language Speech, November 25 to 28, 2007, Florianópolis, Santa Catarina, Brazil, 473-476. http://www.nupffale.ufsc.br/newsounds/Papers/42.Sustarsic_Ratislav.pdf. 
(2009) "Pronunciation Errors in a Reading Task for Students of English." In: M. Ashby/J. Maidment (eds), PTLC 2009: Proceedings. London: UCL, 66-69. https:// www.ucl.ac.uk/pals/study/cpd/cpd-courses/ptlc/proceedings_2009

(2010) "Position of the Nucleus in an Intonation Phrase in English and Slovene." In: V. Mildner /M. Liker (eds), Proizvodnja i percepcija govora: [profesoru Damiru Horgi povodom njegovog sedamdesetog rođendana]. Zagreb: FF press [i. e.] Filozofski fakultet Sveučilišta u Zagrebu/Odsjek za fonetiku/Odjel za fonetiku Hrvatskoga filološkog društva, 351-362.

(2011) "Application of a Speech Archive Analysis to English Pronunciation Teaching." In: M. Brala Vukanović/I. Vodopija Krstanović (eds), The Global and Local Dimensions of English: Exploring Issues of Language and Culture. Wien [etc.]: LIT, 59-66.

(2011) "Position of the Nucleus in an Intonation Phrase in English and Slovene." In: Z. Ančevski/R. Bužarovska (eds), English Studies in a European/Global Context: Current Issues, Future Trends: Proceedings: International Conference: 50th Anniversary of the Department of English Language and Literature. Skopje: Filološki fakultet "Blaže Koneski, 73-83.

(2012) "Learning from Students' Errors: English Phonetics Theory Exam." In: T. Paunović/B. Čubrović (eds), Exploring English Phonetics. Newcastle upon Tyne: Cambridge Scholars Publishing, 197-205.

(2013) “An Evaluation of Tasks in English Phonetics Tests." In: J. Przedlacka/J. A. Maidment/ M. Ashby (eds), Proceedings of PTLC 2013: Papers from the Phonetics Teaching and Learning Conference, London, 8-10 August 2013. London: Phonetics Teaching and Learning Conference, 91-94. https://www.ucl.ac.uk/pals/study/cpd/ cpd-courses/ptlc/proceedings_2013

(2013) "Minimal Pairs in English Phonetics Teaching." In: B. Čubrović/T. Paunović (eds), Focus on English Phonetics. Newcastle upon Tyne: Cambridge Scholars Publishing, 183-190.

(2013) "Tonski potek in mesto jedra $\mathrm{v}$ dopolnjevalnih vprašanjih v slovenščini: ponazoritev s primeri iz govornega korpusa Gos: (vprašanja z zaimkom kaj)." In: H. Tivadar (ed.), Aktualna vprašanja slovanske fonetike. Ljubljana: Znanstvena založba Filozofske fakultete, 25-33.

\section{BOOK REVIEWS}

(1995) "Longman Pronunciation Dictionary - Wellsov slovar angleške izgovorjave." Vestnik DTJK 29/1-2, 286-298.

(1997) "Nov slovar angleške izgovorjave: English pronouncing dictionary, Cambridge University Press." Vestnik DTJK 31/1-2, 356-361.

\section{VARIA}

(1999) “14. mednarodni kongres fonetičnih znanosti ICPHS 99.” Vestnik DTJK 33/12, 499-501. [Co-authored with Jasmina Markič]. 
(2008) Splošni angleško-slovenski slovar. Ljubljana: Rokus Klett. [Redactor]

(2008) Šolski slovar, Angleščina: angleško-slovenski in slovensko-angleški. Ljubljana:

Rokus Klett. [Redactor]

(2009) Splošni slovensko-angleški slovar. Ljubljana: Rokus Klett. [Redactor]

\section{AUTHOR OF PHONETIC TRANSCRIPTION}

BERCE, Sonja (1989) Angleščina za potovanja in prosti čas. Maribor: Obzorja. Reprinted in 1993.

KING-VIDETIČ, Lori/Janez SKELA (1993) Angleški jezik 3 = Touchstone 3, Učbenik. Ljubljana: Tangram.

MARENDIČ, Eleonora/Janez SKELA (2000) Angleški jezik 4 = Touchstone 4, Učbenik. Ljubljana: Tangram. Reprinted in 2002.

KOMAC, Daša (2001) Angleško-slovenski in slovensko-angleški splošni slovar = English-Slovenian and Slovenian-English Desk Dictionary. 1st ed. Ljubljana: Cankarjeva založba.

KING-VIDETIČ, Lori/Eleonora MARENDIČ/Janez SKELA (2003) Angleški jezik 4 = Touchstone 4, Delovni zvezek. Ljubljana: Tangram.

MARENDIČ, Eleonora/Janez SKELA (2003) Angleški jezik 4 = Touchstone 4, Učbenik. Ljubljana: Tangram.

KING-VIDETIČ, Lori/Eleonora MARENDIČ/Janez SKELA (2004) Angleški jezik 4 = Touchstone 4, Delovni zvezek. Ljubljana: Tangram.

MARENDIČ, Eleonora/Janez SKELA (2004) Angleški jezik 4 = Touchstone 4, Učbenik. Ljubljana: Tangram.

KOMAC, Daša (2007) Angleško-slovenski in slovensko-angleški splošni slovar = English-Slovenian and Slovenian-English Desk Dictionary. 2nd ed. Ljubljana: Cankarjeva založba.

\section{EDITOR}

ŠUŠTARŠIČ, Rastislav/Meta GROSMAN (eds) (1998) Angleški jezik in književnost: študijski program. Ljubljana: Filozofska fakulteta/Oddelek za anglistiko in amerikanistiko.

2004-2014. ELOPE, English Language Overseas Perspectives and Enquiries, edited by Smiljana Komar and Uroš Mozetič, Šuštaršič, Rastislav (member of the editorial board). Ljubljana: Slovene Association for the Study of English/Ljubljana University Press, Faculty of Arts.

\section{TRANSLATOR}

LENČEK, Rado L. (1996) Izbrane razprave in eseji. Ljubljana: Slovenska matica. [Translated with Marta PIRNAT-GREENBERG]. 


\section{SUPERVISOR OF DOCTORAL DISSERTATIONS}

VINTAR, Špela (2003) Uporaba vzporednih korpusov za računalniško podprto ustvarjanje dvojezičnih terminoloških virov. University of Ljubljana.

JURANČIČ, Klementina (2004) The Pronunciation of English in Slovenia: (English Spoken by Slovene Learners, Its Development and Factors Influencing It). University of Ljubljana.

ČEBRON, Neva (2007) Opredeljevanje osrednjega strokovnega besednjaka z analizo korpusa angleških besedil in vzporejanjem strokovne terminologije $v$ angleščini in slovenščini. University of Ljubljana.

BRATOŽ, Silva (2009) Metafore našega časa: kontrastivna analiza konceptualnih metafor $v$ političnem diskurzu. University of Ljubljana.

\section{SUPERVISOR OF MASTER'S THESES}

BRKAN, Metka (2000) Leksikografska obdelava angleškega in slovenskega besedišča na področju konfekcijske tehnologije. University of Ljubljana.

KANSKY-ROŽMAN, Ženja (2001) Angleško-slovenska kontrastivna analiza jezika borze. University of Ljubljana.

BRATOŽ, Silva (2002) Konceptualne metafore v poslovnih besedilih. University of Ljubljana.

HROVAT, Marjeta (2002) V slovenščino prevzeto angleško poslovno izrazje in možnosti prevajanja tega izrazja v slovenščino. University of Ljubljana.

SIRK, Saša (2003) Značilnosti jezika stripov v angleškem in slovenskem jeziku: vizualna in zvočna motiviranost jezikovnih znakov. University of Ljubljana. 